\author{
LIDIJA MILOŠEVIĆ ${ }^{1}$ \\ EMINA MIHAJLOVIĆ 1 \\ AMELIJA ĐORĐEVIĆ \\ JASMINA RADOSAVLJEVIĆ ${ }^{1}$ \\ ${ }^{1}$ Faculty of Occupational Safety, \\ University of Nis, Serbia \\ lidija.milosevic@znrfak.ni.ac.rs, \\ emina.mihajlovic@znrfak.ni.ac.rs, \\ amelija.djordjevic@znrfak.ni.ac.rs, \\ jasmina.radosavljevic@znrfak.ni.ac.rs
}

\section{GENERAL PRINCIPLES AND CHARACTERISTICS OF FORMATION AND OUTBREAK OF SANITARY LANDFILL FIRES}

Abstract: This paper discusses fires that occur in sanitary landfills as a result of oxidation processes in the landfill body. The paper provides an overview of the causes and incidence of landfill fires, as well as their classification. Finally, it analyzes fire occurrence indicators.

Key words: landfill, fire, waste, landfill gas, indicators of fires.

\section{INTRODUCTION}

Waste disposal in landfills may lead to unpleasant odours, accumulation of landfill gases, fires and explosions, greenhouse effect, surface and ground water pollution, soil pollution, increased vehicle noise, workers' health risk of various typical and atypical infectious diseases as well as diseases caused by air pollution, uncontrolled scattering of lightweight waste, etc. Figure 1 shows the reported percentage of the most common landfill processes and occurrences that degrade the environment.

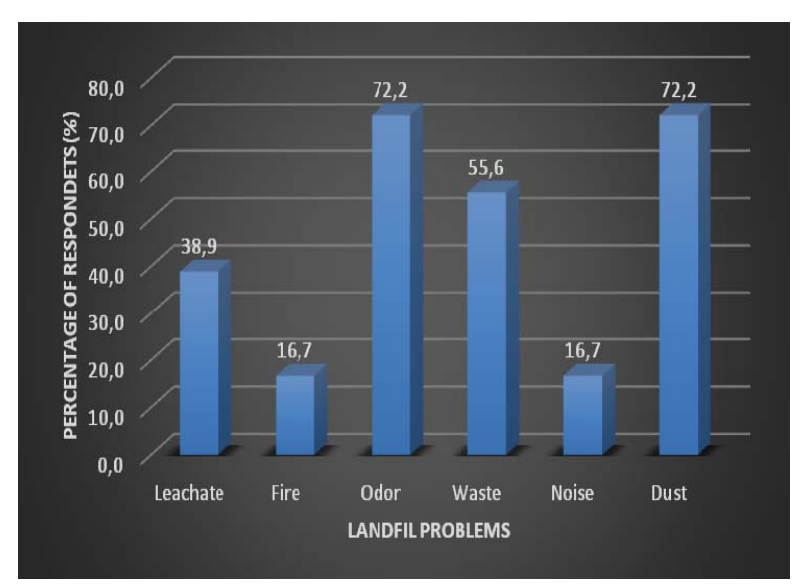

Figure 1. Percentage of the most common landfill processes and occurrences that degrade the environment [1]

Regardless of the low reported percentage of the occurrence of fires and explosions in relation to other phenomena, they still entail the highest risk and the most serious consequences to the environment, which requires a special approach and analysis of all their relevant parameters and causes. The serious nature of this issue is reflected in the data reported by the Sector for Emergency Management of the Republic of Serbia, according to which there were 877 landfill fires in Serbia in 2015.

\section{LANDFILL FIRE CAUSES}

It is difficult to determine with precision what causes landfill fires since there are numerous different factors contributing to their formation and outbreak. The factors influencing landfill gas ignition are complex both for their physicochemical properties and for their incidence and duration. Out of the total percentage of landfill ignition factors, the origin of about $40 \%$ cannot be determined. It is known that ca. $20 \%$ of fires occur due to smouldering waste, which consists of materials with different ignition points (e.g. cigarettes, matches, paper, fabrics, etc.) [2]. It is also known that about $5 \%$ of landfill fires are caused by spontaneous combustion, about $7 \%$ by reignition of a previously suppressed fire, and about $8 \%$ are due to insufficient control of open fires.

\section{FIRE OUTBREAK PERIODS}

According to statistical data, the most common fire outbreak period is between March and August, which is when $60 \%$ of the total annual landfill fires occur (Figure 2). The registered percentage of landfill fires is $11.2 \%$ in July, $10.6 \%$ in April, and $9.9 \%$ in May, which, combined, constitutes one third of the total annual fires. Such monthly incidence is explained by the presence of dominant fire factors, such as increased air temperature and decreased air humidity.

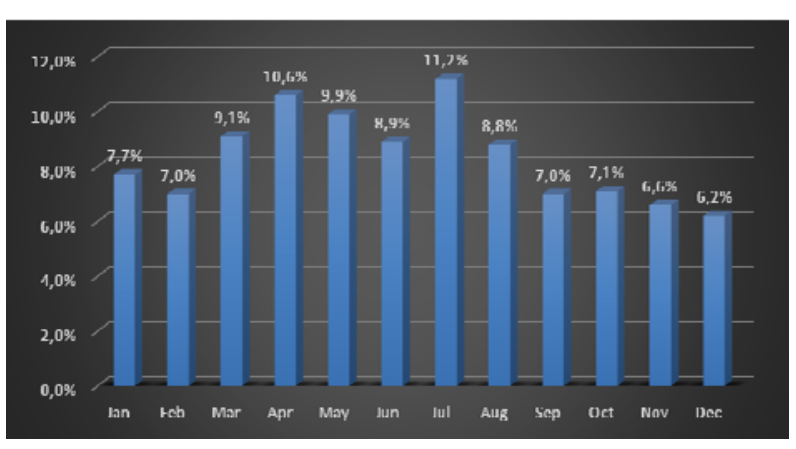

Figure 2. Monthly incidence of landfill fires [3] 
Landfill fires caused by spontaneous combustion (Figure 3) gradually increase in frequency with the decrease in air temperature and changes in other meteorological conditions. These fires occur most frequently during October (10.6\%) and November $(10.6 \%)$.

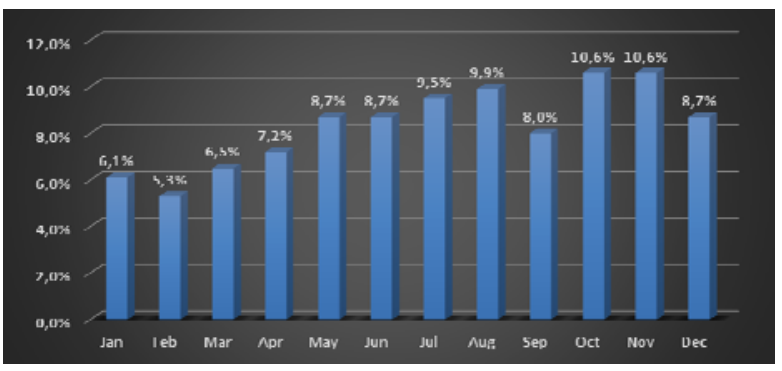

Figure 3. Monthly incidence of landfill fires caused by spontaneous combustion [3]

Insufficiently compacted inert material can allow the oxygen from the air to penetrate into the landfill, accelerate oxidation, or contribute to complete oxidation of a partially oxidized gas. Oxidation is accompanied by the release of heat in the landfill body, and even a slightly higher degree of oxidation poses a fire risk. Penetration of ambient air into the landfill body can also be increased due to the difference in barometric pressure between the landfill body and ambient air. These processes, which are particularly prominent in the spring or late autumn, are caused by strong winds and atmospheric changes that heat and cool the landfill surface.

\section{FIRE-RELATED EVENTS}

Landfill fires entail a series of dominant events, such as flames $(34 \%)$, unpleasant odours $(28 \%)$, smoke $(10 \%)$, landfill surface depressions $(21 \%)$, etc. Other events (7\%) include emissions of incomplete products of combustion and leachate outflow from fire suppression activities.

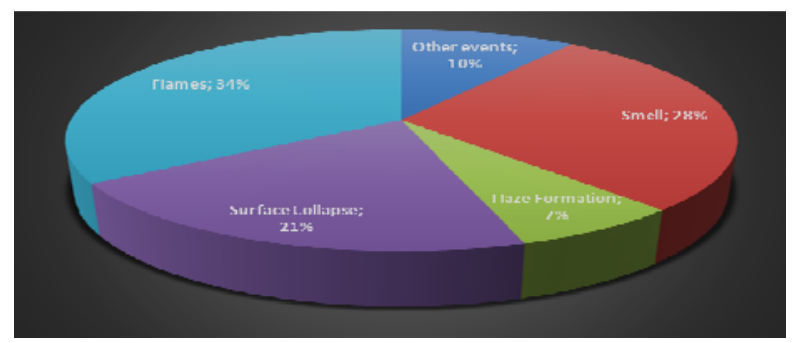

Figure 4. Fire-related events [4]

The duration period of landfill fires and their accompanying events can last from a few days to a few months and even a year (Figure 5).

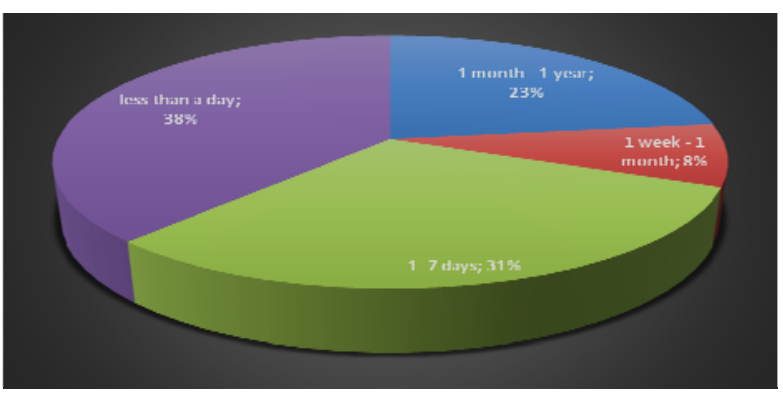

Figure 5. Landfill fire duration [4]

\section{LANDFILL FIRE CLASSIFICATION}

According to the amount of inflammable material waste - caught on fire, landfill fires can be classified into four categories [5] :

- Category 1 - easily extinguished fires; include fires on vehicles, equipment, or buildings at the landfill;

- Category 2 - fires on flat surfaces or slopes for waste disposal, which covers less than $200 \mathrm{~m}^{3}$ of inflammable waste;

- Category 3 - fires that cover 200-5,000 $\mathrm{m}^{3}$ of inflammable waste and require up to a week to be extinguished;

- Category 4 - fires that cover more than $10,000 \mathrm{~m}^{3}$ of inflammable waste and require more than two weeks to be extinguished.

According to the point of origin at the landfill, fires can be classified into [3]:

- fires in the active landfill sections, which are the most common $(77 \%)$;

- vehicle fires, including dustcarts, presses, compactors, and other vehicles (4\%);

- wood, thicket, and grass fires from landfill fire propagation $(12 \%)$;

- fires in landfill buildings - administrative offices and auxiliary facilities (e.g. guardhouse, weighing scales) $(7 \%)$.

According to the manner of combustion, landfill fires can be classified into:

- flaming fires (open-flame combustion) and

- smouldering fires (smouldering combustion without flames).

Flaming fires are typically surface fires, whereas smouldering fires are usually underground fires.

Accordingly, landfill fires can also be classified into [6]:

- surface fires and

- underground fires.

\subsection{Surface fires}

Surface fires originate in the active sections of the landfill where waste is deposited daily. The inflammable material comprises incompact waste, a few days to a few weeks old, usually at the depth of $0.31 \mathrm{~m}$ to $1.22 \mathrm{~m}$, in the aerobic decomposition phase. These fires can become more intensive due to landfill gas (methane), which can spread them across the entire 
landfill. Surface fire usually burn at relatively low temperatures and emit thick white smoke and products of incomplete combustion. Their causes include: disposal of unnoticed smouldering materials in the landfill; excessive accumulation of landfill gas in the landfill body; damage of the degassing system; inadequate landfill waste management; landfill accidents and damage; etc.

\subsection{Underground fires}

Underground landfill fires originate deep beneath the landfill surface, in the deposited waste that is months or years old. They usually occur due to overload of the landfill gas collection system or due to spontaneous combustion. Waste often oxidizes in the immediate vicinity of gas wells or near the landfill surface, which allows the oxygen to penetrate into the landfill body, which in turn leads to fast oxidation of organic waste. The most common cause of underground landfill fires is the increased concentration of oxygen in the landfill body, which increases bacterial activity and raises temperature (aerobic decomposition). These so-called 'hot spots' can come into contact with methane and cause a fire. Such fires tend to smoulder continuously for weeks and even months, without any visible flames or large volumes of smoke. The fire spreads imperceptibly within the landfill body until the surface layer collapses, until there is a hole in the surface, or until smoke becomes visible. Underground fires are detected in the gas collection systems due to increased temperature at the top of the gas well or due to appearance of soot. These fires produce inflammable and toxic gases (e.g. carbon monoxide), which can damage the systems for landfill filtrate and gas collection. They are usually more difficult to extinguish than surface fires.

According to their point of origin in the landfill body, underground fires can be classified into (Figure 6):

1) fires in gas wells near the landfill surface;

2) fires in gas wells within the landfill body;

3) fires inside the landfill body;

4) fires near the landfill surface.

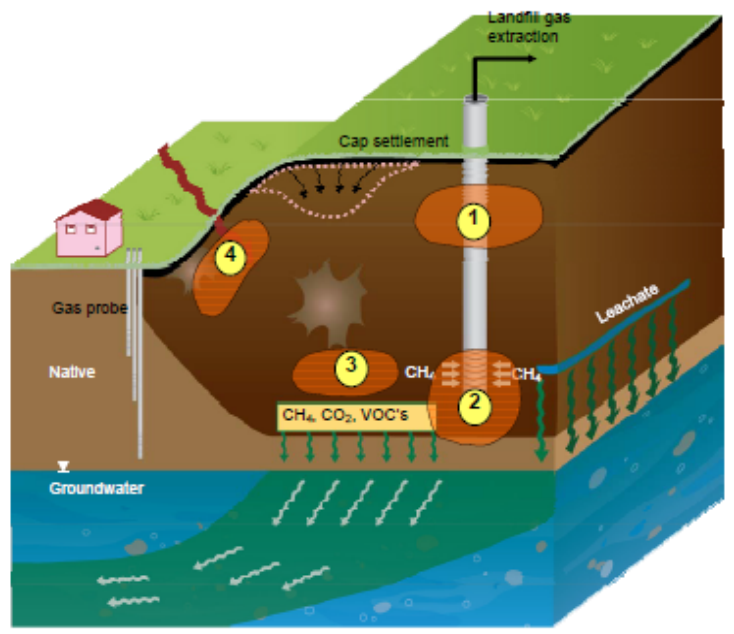

Figure 6. Underground fire points of origin [7]

\section{INDICATORS FOR DETECTING HOT SPOTS IN THE LANDFILL BODY}

There are four main indicators of underground landfill fires:

- smoke and odours from the landfill;

- increased temperature in gas collection systems and measuring points;

- occurrence of cracks, subsidence, or depressions;

- changed concentrations of landfill gas components.

The presence of hot spots, which determine the point of origin of underground fires, can be detected based on depressions and the smoke and odours coming from the landfill surface. They only indicate the part of the landfill where the fire originated, but not the depth. More precise locations of 'hot spots' are determined through the examination of the concentrations of $\mathrm{CO}$ and other landfill gas components by means of a quantitative laboratory analysis. Landfill gas monitoring during a fire reveals a change in the concentrations [8] (Table 1).

Table 1. Changes in concentrations of landfill gas components during a fire

\begin{tabular}{lccc}
\hline Gas & $\begin{array}{c}\text { Indication } \\
\text { of } \\
\text { potential } \\
\text { developme } \\
\text { nt }\end{array}$ & $\begin{array}{c}\text { Background } \\
\text { concentratio } \\
\text { ns }\left(\%_{\text {vol }}\right)\end{array}$ & $\begin{array}{c}\text { Hot spot area } \\
\text { concentratio } \\
\text { ns }\left(\%_{\text {vol }}\right)\end{array}$ \\
\hline Methane & Decrease & $55-56$ & 10 \\
\hline $\begin{array}{l}\text { Carbon } \\
\text { dioxide }\end{array}$ & Decrease & $43-44$ & 16 \\
\hline Oxygen & Increase & 0.05 & 8 \\
\hline $\begin{array}{l}\text { Carbon } \\
\text { monoxide }\end{array}$ & Increase & $\begin{array}{c}0.0006- \\
0.0019\end{array}$ & 0.0052 \\
\hline Hydrogen & Increase & $0.06-0.07$ & 1.6 \\
\hline
\end{tabular}

These data suggest that $\mathrm{CO}$ has the highest volume percentage and that it is justifiably used as an underground fire indicator. Table 2 shows CO concentration ranges, which are taken as the qualitative probability factor for the occurrence of a fire in the landfill body.

Table 2. Empirical scale for the assessment of fire occurrence in the landfill body

\begin{tabular}{cl}
\hline CO $\left(\%_{\text {vol }}\right)$ & \multicolumn{1}{c}{$\begin{array}{c}\text { Possibility of a fire in the } \\
\text { landfill body }\end{array}$} \\
\hline $0-0.0025$ & No fire \\
\hline $0.0025-0.01$ & Possible fire in the landfill body \\
\hline $0.01-0.05$ & $\begin{array}{l}\text { Possible smouldering fire in the } \\
\text { landfill body }\end{array}$ \\
\hline $0.05-0.1$ & Probable fire in the landfill body \\
\hline$>0.1$ & Fire in the landfill body \\
\hline
\end{tabular}


Since the landfill temperature in the aerobic phase, which lasts from several days to several weeks, ranges from 80 to $90^{\circ} \mathrm{C}$ and, after the transition to the anaerobic phase, which lasts for years, the temperature ranges from 30 to $50^{\circ} \mathrm{C}$, any temperature increase indicates the appearance of hot spots during fires. If gas temperature in a gas well increases without visible smoke or depression, it is difficult to determine the exact point of origin of the underground fire. Fire temperature in the landfill body can be measured with thermocouples [8] (Table 3).

Table 3. Temperature ranges of hot spots in the landfill body

\begin{tabular}{ccc}
\hline Depth (m) & $\begin{array}{c}\text { Temperature in } \\
\text { hot spot area }\left({ }^{\circ} \mathrm{C}\right)\end{array}$ & $\begin{array}{c}\text { Background } \\
\text { waste } \\
\text { temperature }\left({ }^{\circ} \mathrm{C}\right)\end{array}$ \\
\hline $3-4$ & $40-60$ & $7-22$ \\
\hline 5 & $40-60$ & $22-35$ \\
\hline 10 & 550 & $39-65$ \\
\hline 15 & 105 & $45-55$ \\
\hline $25-30$ & 70 & $30-40$ \\
\hline
\end{tabular}

The temperature in the landfill body depends on the amount and composition of inflammable waste. Table 4 shows the amounts of heat released during the combustion of different types of waste.

Table 4. Calorific values of municipal solid waste components [9]

\begin{tabular}{lccc}
\hline \multirow{4}{*}{ Component } & \multicolumn{3}{c}{ Caloric values $(\mathrm{kJ} / \mathrm{kg})$} \\
\cline { 2 - 4 } & $\begin{array}{c}\text { As } \\
\text { received }\end{array}$ & Dry & $\begin{array}{c}\text { Moisture/ash } \\
\text { free }\end{array}$ \\
\hline Paper & 15750 & 17530 & 18650 \\
\hline $\begin{array}{l}\text { Corrugated } \\
\text { boxes }\end{array}$ & 16380 & 17280 & 18260 \\
\hline $\begin{array}{l}\text { Plastic coated } \\
\text { paper }\end{array}$ & 17070 & 17910 & 18470 \\
\hline $\begin{array}{l}\text { Waxed milk } \\
\text { carton }\end{array}$ & 26350 & 27290 & 27660 \\
\hline Lawn grass & 4760 & 19250 & 20610 \\
\hline Leaves & 18490 & 20540 & 21460 \\
\hline Green logs & 4870 & 9740 & 9840 \\
\hline $\begin{array}{l}\text { Flowering } \\
\text { plants }\end{array}$ & 8560 & 18580 & 19590 \\
\hline $\begin{array}{l}\text { Wood and } \\
\text { bark }\end{array}$ & 19570 & 19940 & 20140 \\
\hline Rubber & 25930 & 26230 & 29180 \\
\hline Upholstery & 16120 & 17320 & 17800 \\
\hline Polystyrene & 38020 & 38090 & 38230 \\
\hline PVC & 22590 & 22640 & 23160 \\
\hline
\end{tabular}




\section{OPŠTI PRINCIPI I KARAKTERISTIKE FORMIRANJA I NASTANKA POŽARI NA SANITARNIM DEPONIJAMA \\ Lidija Milošević, Emina Mihajlović, Amelija Đorđević, Jasmina Radosavljević}

Apstrakt: U radu su prikazani požari koji se nastaju na sanitarnim deponijama kao posledica formiranja procesa oksidacije u telu deponije. Dat je pregled uzroka formiranja i učestalost procesa nastajanja požara kao i njihova kategorizacija. Posebno je dat prikaz izbora indikatora koji su u funkciji nastanka požara.

Ključne reči: deponija, požar, otpad, deponijski gas, indikatori požara. 